\title{
The Kinetic Model for Decolorization of Commercial Reactive Red 120 Azo Dye Aqueous Solution by the Fenton Process and Study the Effect of Inorganic Salts
}

\author{
Ahmed Khudhair Hassan ${ }^{1,}$ *, Hasan Fadhil AL-Rubai ${ }^{1}$ and Hadi Hassan AL-Shamary ${ }^{2}$ \\ ${ }^{1}$ Environment and Water Directorate, Ministry of Science and Technology, Baghdad-Iraq. \\ ${ }^{2}$ Department of Chemistry, College of Science, University of Al-Mustansiriya, Baghdad-Iraq. \\ *Corresponding Author: ahmedkhh71@yahoo.om
}

\begin{abstract}
The degradation of a commercial azo dye Reactive Red 120 (RR120) in synthetic aqueous solution using Fenton's oxidation has been studied. The influence of different reaction parameters such as $\mathrm{pH}$, hydrogen peroxide, ferrous sulfate, and the RR 120 concentration on the oxidative degradation of RR 120 have been appraised. The optimal reaction conditions were determined and it was found to be $\mathrm{pH}=3.50,\left[\mathrm{H}_{2} \mathrm{O}_{2}\right]=1.1 \times 10^{-3} \mathrm{M},\left[\mathrm{Fe}^{2+}\right]=1.0 \times 10^{-4} \mathrm{M}$ for $[\mathrm{RR} 120]=7.5 \times 10^{-5} \mathrm{M}$. Under optimal conditions, $96.0 \%$ decolorization efficiency of dye in aqueous solution was achieved after $15 \mathrm{~min}$ of reaction. The effect of azo bond loading ( $L_{\text {azo bond }}$ ), from 0.25 to 1.0 , and $\mathrm{pH}$ values from 2.5 to 5.0 were estimated on RR 120 color removal kinetic rates. A correlation between the kinetic of the color removal rates ( $\mathrm{ln}_{2}$ ) versus $L_{\text {azo bond }}$ was carried out at the different $\mathrm{pH}$ levels. The color removal rate increased linearly with decreasing $L_{\text {azo }}$ bond, in the order of $\mathrm{pH}: 3.5>5.0>2.5$. All the experimental data were analyzed using the first and second-order kinetic models. The second-order provides the best correlation of the data. 67\% Chemical Oxygen Demand (COD) removal efficiency of the RR 120 were achieved after $15 \mathrm{~min}$ of reaction by fixing the initial $\mathrm{H}_{2} \mathrm{O}_{2} / \mathrm{Fe}^{2+}$ molar ratio, COD loading factor $\left(L_{\mathrm{COD}}\right)$, and $\mathrm{pH}$ at $11,0.25$ and 3.5 , respectively. Also, the effects of various inorganic anions (such as $\mathrm{Cl}^{-}, \mathrm{SO}_{4}{ }^{2-}, \mathrm{CO}_{3}{ }^{2-}$, etc.) on the oxidation efficiency of Fenton were studied. This study can benefit planners who deal with contaminated textile wastewater using chemical treatment by advanced oxidation technologies.
\end{abstract}

[DOI: 10.22401/JNUS.21.3.09]

Key words: Fenton, Kinetics, Azo dye, Advanced oxidation processes, Chemical oxygen demand.

\section{Introduction}

The textile industry is a main source of effluent industrial wastewater; due to a more consumption of water during process operations. This industrial wastewater contains chemicals such as alkalis, acids, dyes, surfactants and matter high in biological oxygen demand [1]. Thus, there is environmental effect; due to the textile industry is used more water than any other industry; globally, virtually all wastewater discharged is highly polluted. Show that the daily water consumption of an average sized textile mill about 50 gal per $\mathrm{kg}$ of fabric manufactured daily [2]. The most abundant of these compounds are azo dyes, which represent $70 \%$ of the world dye production. Large volumes of industrial wastewater with highly levels of azo dyes (about $250 \mathrm{mg} \mathrm{L}^{-1}$ ) are daily discharged by many industries around the world in the surface water. The stability and complexity of the dye structure is more difficult to degradation when it is present in the textile wastewater [3]. Therefore, the mineralization of dyes generated by textile industry is a main challenge and an environmental concern [4]. There are several methods currently used to remove wastewater contamination in the fabric; but they are not universally applicable and are not cost effective for all dyes [5]. In the last years, the problem of high toxic level of wastewater has been tried by Advanced Oxidation Processes (AOPs) [6]. AOPs are based on the in-situ generation of hydroxyl radical $\left(\mathrm{HO}^{\circ}, \mathrm{E}^{\circ}\right.$ $\left.\left(\mathrm{HO}^{\circ} / \mathrm{H}_{2} \mathrm{O}\right)=2.80 \mathrm{~V}\right)$ [7]. The Fenton system is one of the most techniques used to degrade different organic pollutants such as azo-dyes by hydroxyl free radical generated from the hydrogen peroxide molecules reduction with $\mathrm{Fe}^{2+}$ ions at acidic $\mathrm{pH}$ [8].

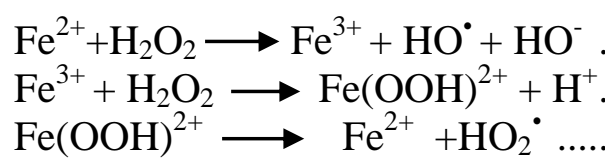


In Fenton oxidation process, hydroxyl free radical prefer to attack the azo bond $(-\mathrm{N}=\mathrm{N}-)$ of the dye molecule by cleaving it to produce aromatic amines and inorganic ions such as $\mathrm{NH}_{4}{ }^{+}[9,10]$. For treatment industrial textile wastewater containing dyes; the AOPs are effective techniques for degradation aromatic compounds due to the electrophilic aromatic substitution of hydroxyl radical which then lead to open the aromatic ring [11, 12]. The goal of the other treatment is reducing the chemical oxygen demand (COD) of the industrial textile wastewater. Typically, these two targets require different chemical reagents such as $\mathrm{H}_{2} \mathrm{O}_{2}$ and $\mathrm{Fe}^{2+}$ according to either azo bond or COD loadings [13,14]. In this manuscript, reports of the color removal or COD removal kinetics of the Reactive Red 120 (RR 120), which contains diazo bond, by Fenton oxidation process. The goals of this study were: (1) to determine the best molar ratio of $\mathrm{H}_{2} \mathrm{O}_{2} / \mathrm{Fe}^{2+}$ through Fenton oxidation process of RR 120 at optimum $\mathrm{pH}$ according to the color removal kinetics by fixing $\mathrm{Fe}^{2+}$ while varying $\mathrm{H}_{2} \mathrm{O}_{2}$ and vice versa; (2) to estimate the effects of either azobond loading factor $\left(L_{\text {azobond }}\right)$ or COD loading factor $\left(L_{\mathrm{COD}}\right)$ at different $\mathrm{pH}$ values on the color removal kinetic rates or COD removal of RR 120 by Fenton oxidation process at the optimum conditions; (3) Finally, to study the effects of inorganic anions such as chloride, sulfate, carbonate and bicarbonate at optimum conditions on degradation of RR 120.

\section{Experimental \\ Chemicals}

Reactive red 120 (RR 120) (Ciba Specialty Chemicals Inc.) was a gift from Al-Kut Textile Factory, Iraq. $\mathrm{H}_{2} \mathrm{O}_{2}(30 \% \mathrm{~W} / \mathrm{W}), \mathrm{Na}_{2} \mathrm{SO}_{3}$ and $\mathrm{FeSO}_{4} \cdot 7 \mathrm{H}_{2} \mathrm{O}$ were obtained from (Merck and $\mathrm{BDH}) . \mathrm{NaOH}(99 \%)$ and $\mathrm{H}_{2} \mathrm{SO}_{4}(99 \%)$ were used to adjust the $\mathrm{pH}$ which was purchased from Appli Chem $(\mathrm{GmbH})$. A solution 0.062 $\mathrm{M}$ of ammonium metavanadate $\mathrm{NH}_{4} \mathrm{VO}_{3}$ (BDH) was prepared in $0.58 \mathrm{M}$ of $\mathrm{H}_{2} \mathrm{SO}_{4}$ and used in quantification $\mathrm{H}_{2} \mathrm{O}_{2}$ concentration. $\mathrm{KCl}$ (99\%), $\mathrm{NaCl}$ (99\%), $\quad \mathrm{Na}_{2} \mathrm{CO}_{3} \quad$ (99.0\%), $\mathrm{NaHCO}_{3}(98 \%), \mathrm{Na}_{2} \mathrm{SO}_{4}(99 \%)$ and $\mathrm{K}_{2} \mathrm{SO}_{4}$ (99\%) were obtained from Fluka. All solutions were prepared using distilled water. The main characteristics and chemical structure of RR 120 dye are as shown in Table (1).
Table (1)

Characteristics of Reactive red dye 120.

\begin{tabular}{||c||c||}
\hline \hline Properties & Value \\
\hline \hline $\begin{array}{c}\text { Chemical } \\
\text { formula }\end{array}$ & $\mathrm{C}_{44} \mathrm{H}_{24} \mathrm{Cl}_{2} \mathrm{~N}_{14} \mathrm{Na}_{6} \mathrm{O}_{20} \mathrm{~S}_{6}$ \\
\hline \hline Molar Mass & 1470 \\
\hline $\begin{array}{c}\text { Chemical } \\
\text { Structure }\end{array}$ & Biazo \\
\hline $\begin{array}{c}\text { Functional } \\
\text { group }\end{array}$ & Bright red, 535 \\
\hline $\begin{array}{c}\text { Color, } \lambda \text { max } \\
\text { (nm) }\end{array}$ & \\
\hline
\end{tabular}

\section{Experimental Procedure}

The color removal of the azo dye RR 120 solutions was followed quantitatively by measuring the decrease in absorbance at $\lambda \max =535 \mathrm{~nm}$ using (UV/VIS, Model SP3000 OPTIMA) spectrophometer. The chemical oxygen demand (COD) was determined by the method described in EPA method 410.4 [15]. $\mathrm{H}_{2} \mathrm{O}_{2}$ was quantified spectrophotometrically as described by Nogueira [16]. The degradation of RR 120 was carried out by Fenton process using a batch reactor (total volume of 1L) under constant agitation with a magnetic stirrer and room temperature ranged from $35 \pm 2{ }^{\circ} \mathrm{C}$. The experiments were conducted as the following:

1) To achieve the effects of the initial $\mathrm{H}_{2} \mathrm{O}_{2}$ concentration (ranging from $1.1 \times 10^{-4}$ to $\left.5.0 \times 10^{-3} \mathrm{M}\right)$ on the color removal (decolorization) kinetics of RR $120\left(7.5 \times 10^{-5}\right.$ $\mathrm{M})$, Fenton oxidation experiments were conducted at a fixed $\mathrm{Fe}^{2+}$ concentration of $1.0 \times 10^{-4} \mathrm{M}$ and initial $\mathrm{pH}$ 3.5. A desired amount of $\mathrm{FeSO}_{4} .7 \mathrm{H}_{2} \mathrm{O}$ was added to each experiment. The $\mathrm{pH}$ was then adjusted to the required value using either $\left(1 \mathrm{M} \mathrm{H}_{2} \mathrm{SO}_{4}\right.$ or 1 M NaOH); the amount of $\mathrm{H}_{2} \mathrm{O}_{2}$ was calculated according to the predetermined $\mathrm{H}_{2} \mathrm{O}_{2}$ concentration; and was added to the batch reactor. For monitoring the RR 120 concentration during the color removal 
process, $10 \mathrm{~mL}$ of sample was taken out at 1 , $3,5,7,10,15,20,30,45$ and $60 \mathrm{~min}$ and were analyzed immediately.

2) The effects of $\mathrm{Fe}^{2+}$ concentration ranged from $1.0 \times 10^{-5}$ to $1.0 \times 10^{-3} \mathrm{M}$ on decolorization rate of RR $1207.5 \times 10^{-5} \mathrm{M}$ solution were studied under the optimal condition of $\mathrm{H}_{2} \mathrm{O}_{2}$ concentration of $1.1 \times 10^{-3}$ $\mathrm{M}$ at $\mathrm{pH} 3.5$.

3) The optimum molar ratio $\mathrm{H}_{2} \mathrm{O}_{2} / \mathrm{Fe}^{2+}$ was experimentally determined by changing either $\mathrm{H}_{2} \mathrm{O}_{2}$ or $\mathrm{Fe}^{2+}$ concentrations as described in the first and second steps. In the literature review, $\mathrm{H}_{2} \mathrm{O}_{2}$ and $\mathrm{Fe}^{2+}$ doses were determined by carring out several experiments at different ratios of $\mathrm{H}_{2} \mathrm{O}_{2}$ and $\mathrm{Fe}^{2+}$ doses $[17,18]$.

4) Experiments were carried out at three $\mathrm{pH}$ values (2.5, 3.5 and 5.0) and at different $L_{\text {azobond }}$ for the Fenton oxidation process. The color removal (decolorization) kinetic of $7.5 \times 10^{-5} \mathrm{M}$ of $\mathrm{RR} 120$, was studied at different $L_{\text {azo bond }}(1.0,0.75,0.5$, and 0.25$)$ which are equivalent to $\mathrm{H}_{2} \mathrm{O}_{2}$ concentrations $\left(5 \times 10^{-4} ; 2.0 \times 10^{-4} ; 3.0 \times 10^{-4}\right.$; and $\left.6.0 \times 10^{-4} \mathrm{M}\right)$, respectively for the destruction of azo group bond at a fixed $\mathrm{H}_{2} \mathrm{O}_{2} / \mathrm{Fe}^{2+}$ molar ratio of 11 .

5) The COD removal of RR 120, was studied at different $L_{\mathrm{COD}}(1.0,0.75,0.5$, and 0.25$)$ at $\mathrm{H}_{2} \mathrm{O}_{2} / \mathrm{Fe}^{2+}$ molar ratio equal to 11 . Different $\mathrm{H}_{2} \mathrm{O}_{2}$ concentrations: $3.8 \times 10^{-3} ; 5.2 \times 10^{-3}$; $7.76 \times 10^{-3}$; and $1.0 \times 10^{-2} \mathrm{M}$ equivalent to $L_{\mathrm{COD}}(1.0,0.75,0.5$, and 0.25$)$ were used for the COD removal, because the experimental COD concentration obtained at $7.5 \times 10^{-5} \mathrm{M}$ RR120 solution was $124 \mathrm{mg} \mathrm{O}_{2} \mathrm{~L}^{-1}(\mathrm{COD}=$ $\left.3.64 \times 10^{-3} \mathrm{M}\right)$.

6) The effect of $1.0 \%$ of inorganic salts on decolorization of RR 120 at $\left(7.5 \times 10^{-5} \mathrm{M}\right)$ was investigated. $10 \mathrm{gm}$ of inorganic salt was added to $1 \mathrm{~L}$ batch reactor for each experiment.

7) $100 \mu \mathrm{L} \mathrm{Na} \mathrm{SO}_{3}$ solution $(1 \mathrm{M})$ was added to the all samples before analysis by UV-Vis to ensure removal of the residual $\mathrm{H}_{2} \mathrm{O}_{2}$. Thus, the residual of $\mathrm{H}_{2} \mathrm{O}_{2}$ was destroyed and Fenton reactions was stopped [10, 19]. While to measure the COD concentration in the treated water the interference from residual $\mathrm{H}_{2} \mathrm{O}_{2}$ was removed by addition of $\mathrm{Na}_{2} \mathrm{CO}_{3}(20 \mathrm{~g} / \mathrm{L})$ and placed in a water bath at $90{ }^{\circ} \mathrm{C}$ for $60 \mathrm{~min}$ [20].

\section{Results and discussion}

Results presented in following section are based on batch studies for degradation of Reactive Red 120 (RR 120) by Fenton oxidation. The parameters for color removal (decolorization) efficiencies such as loading azo bond factor ( $L_{\text {azo bond }}$ ) or COD loading factor $\left(L_{\mathrm{COD}}\right)$ was studied; which are defined by Eqs. (4) and (5), respectively [10]. The stoichiometry requirements of Fenton's reagent dose should depend on the amount of available $\mathrm{O}_{2}$ in $\mathrm{H}_{2} \mathrm{O}_{2}$ to produce hydroxyl free radical during the oxidation of azo bond and its organic intermediates [10]. Therefore, the dosage of $\mathrm{H}_{2} \mathrm{O}_{2}$ required should be based on the initial $L_{\text {azo bond, }} L_{\mathrm{COD}}$ of $\mathrm{RR} 120$, and $\mathrm{O}_{2}$ supplied by $\mathrm{H}_{2} \mathrm{O}_{2}$, respectively.

$$
\begin{aligned}
& L_{\text {azo bond }}=\left\{[\text { RR 120 }]_{\text {initial }}(\mathrm{M})\right\} / \mathrm{O}_{\text {2available }}(\mathrm{M}) \\
& L_{\mathrm{COD}}=\left\{\mathrm{COD}_{\text {initial }}(\mathrm{M})\right\} / \mathrm{O}_{\text {2available }}(\mathrm{M})
\end{aligned}
$$

Where RR $120_{\text {initial }}$ and $\mathrm{COD}_{\text {initial }}$ are the initial concentration and the chemical oxygen demand of RR 120 dye, respectively.

\section{Construction of the calibration graphs}

Absorption spectrum of the RR 120 dye aqueous solutions were recorded. Calibration graph of RR 120 was constructed. Into a series of $10 \mathrm{~mL}$ volumetric flasks an increasing volume of RR 120 working solution $(0.01 \mathrm{M})$ were transferred to cover the range of the calibration graph and diluted to the mark with distilled water. The absorbance's was measured at $535 \mathrm{~nm}$ versus the distilled water as reagent blank as shown in Fig.(1).

The concentration of the dye (RR 120) was calculated by Beer-Lambert law at the maximum wavelength $(\lambda \max =535 \mathrm{~nm})$ by the equation:

$\mathrm{A}=1 \varepsilon \mathrm{C}$

Where $\mathrm{A}$ is the absorbance; 1 , is the path length $(\mathrm{cm}) ; \varepsilon$, is the molar absorptivity $\left(\mathrm{L} \mathrm{mol}^{-1} \mathrm{~cm}^{-1}\right)$ and $\mathrm{C}$, is the RR 120dye concentration $(\mathrm{M})$. 




Fig.(1): Calibration graph of RR 120 dye.

Dye color removal (decolorization) efficiency was calculated as follows:

(\%) Dye color removal efficiency $=$

$$
\left(1-\mathrm{C}_{\mathrm{t}} / \mathrm{C}_{0}\right) \times 100
$$

Where $\mathrm{C}_{\mathrm{t}}$ and $\mathrm{C}_{0}\left(\mathrm{~mol} \mathrm{~L}^{-1}\right)$ are the concentrations of RR 120 dye at reaction time $t$ and 0 , respectively. The chemical oxygen demand removal percentage was calculated as follows:

(\%) $\mathrm{COD}$ removal $=\left(1-\mathrm{COD}_{\mathrm{t}} / \mathrm{COD}_{0}\right) \times 100$

Where $\mathrm{COD}_{\mathrm{t}}$ and $\mathrm{COD}_{0}$ are the chemical oxygen demand of RR 120 dye attraction time $\mathrm{t}$ and 0 , respectively.

\section{Effect of the $\mathrm{H}_{2} \mathrm{O}_{2}$ dose on the removal of RR 120}

In the Fenton process, hydrogen peroxide plays an essential role in contaminant removal efficiency. Therefore, it was necessary to find the optimum hydrogen peroxide concentrations. To determine the concentration of $\mathrm{H}_{2} \mathrm{O}_{2}$ giving the maximum decolorization efficiency of RR 120, experiments were conducted, and results obtained are represented in Fig.(2). The RR 120 color removal (decolorization) with concentration of $\left(7.5 \times 10^{-5} \mathrm{M}\right.$ or $\left.100.25 \mathrm{mg} / \mathrm{L}\right)$ was evaluated by of Fenton's oxidation using different concentration of $\mathrm{H}_{2} \mathrm{O}_{2}$ between $\left(1.1 \times 10^{-4}\right.$ and $\left.5 \times 10^{-3} \mathrm{M}\right)$ and fixed amount of ferrous iron $\left(1 \times 10^{-4} \mathrm{M}\right.$ or $\left.5.6 \mathrm{mg} / \mathrm{L}\right)$ to find the optimal oxidant dosage. From Fig.(2) when the hydrogen peroxide concentration was $1.1 \times 10^{-4}$ $\mathrm{M}$ the color removal of RR 120 (40.5\%) was achieved after $10 \mathrm{~min}$ of the reaction. However, increasing the peroxide dosage until $1.1 \times 10^{-3} \mathrm{M}$ a higher color removal was reached $(94.0 \%)$ at $10 \mathrm{~min}$ of Fenton oxidation. At high $\mathrm{H}_{2} \mathrm{O}_{2}$ concentration more than $1.1 \times 10^{-3} \mathrm{M}$, the efficiency of dye removal showed no significant efficiency, which is due to the recombination of hydroxyl radicals with $\mathrm{H}_{2} \mathrm{O}_{2}$, and scavenging of $\mathrm{HO}^{\circ}$ radicals will occur, which can be illustrated by Eq.(9) [21]:

$\mathrm{HO}^{\bullet}+\mathrm{H}_{2} \mathrm{O}_{2} \longrightarrow \mathrm{H}_{2} \mathrm{O}+\mathrm{HO}_{2}{ }^{\circ}$

$k_{1}=2.7 \times 10^{7} \mathrm{M}^{-1} \cdot \mathrm{S}^{-1}$

Therefore, $1.1 \times 10^{-3} \mathrm{M} \mathrm{H}_{2} \mathrm{O}_{2}$ was chosen as the optimum concentration and used in all experiments to assess the effects of $\mathrm{Fe}^{2+}$ concentration on RR 120.

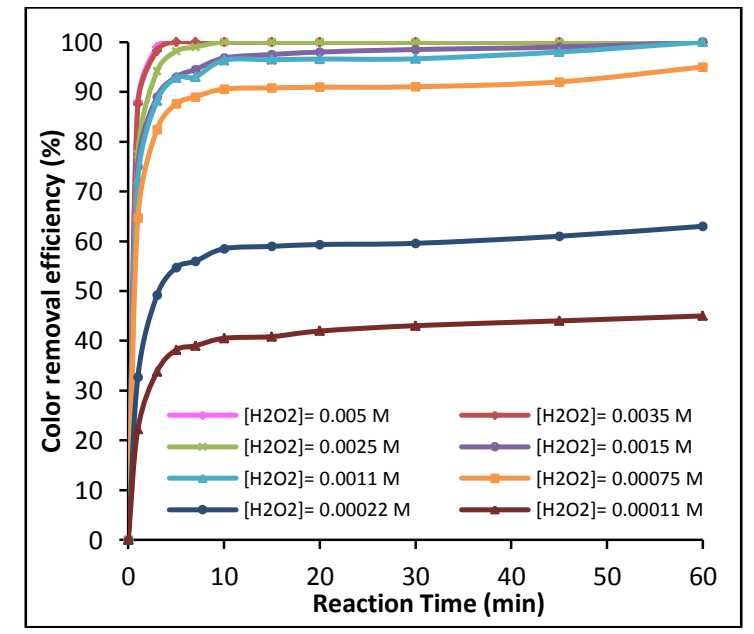

Fig.(2): RR 120 color removal efficiency by

Fenton oxidation at various $\mathrm{H}_{2} \mathrm{O}_{2}$ doses. Experimental conditions: $\left[R R\right.$ 120] $=7.5 \times 10^{-}$ ${ }^{5} \mathrm{M} ;\left[\mathrm{Fe}^{2+}\right]=1.0 \times 10^{-4} \mathrm{M}$ and $\mathrm{pH}=3.5$.

The kinetics of influence of $\mathrm{H}_{2} \mathrm{O}_{2}$ concentration on RR 120 decolorization

The kinetics of Fenton oxidation can be very complicated because of a large number of reactions occur at the same time. Two kinetic models the first-order, and the second-order have been used to fit the experimental data obtained from the color removal processes. Compairing the correlation coefficient $\left(\mathrm{R}^{2}\right)$ obtained from Table (2), it can be seen that the correlation coefficient of the first-order model was not good enough due to the low correlation coefficients, while the secondorder reaction was obviously much better than based on the first- 
Table (2)

First- and second- orders kinetic parameters and regression coefficients for each $\mathrm{H}_{2} \mathrm{O}_{2}$ concentration. Experimental conditions: [RR $120]=7.5 \times 10^{-5} \mathrm{M} ;\left[\mathrm{Fe}^{2+}\right]=1.0 \times 10^{-4} \mathrm{M}$ and $p H=3.5$.

\begin{tabular}{|c|c|c|c|c|c|}
\hline \multirow{2}{*}{$\begin{array}{c}{\left[\mathbf{H}_{2} \mathbf{O}_{2}\right]} \\
(\mathbf{M})\end{array}$} & \multirow[b]{2}{*}{$\mathrm{H}_{2} \mathrm{O}_{2} / \mathrm{Fe}^{+2}$} & \multicolumn{2}{|c|}{ First-order } & \multicolumn{2}{|c|}{ Second-order } \\
\hline & & $\begin{array}{c}\mathrm{K1} \\
\left(\mathrm{min}^{-1}\right)\end{array}$ & $\bar{~} R^{2}$ & $\begin{array}{c}K 2\left(\mathrm{M}^{-1}\right. \\
\left.\min ^{-1}\right)\end{array}$ & $R^{2}$ \\
\hline $5.0 \times 10^{-3}$ & 50 & 1.0423 & 0.9088 & 596468 & 0.9722 \\
\hline $3.5 \times 10^{-3}$ & 35 & 0.8883 & 0.8868 & 297841 & 0.9848 \\
\hline $2.5 \times 10^{-3}$ & 25 & 0.6354 & 0.9053 & 202419 & 0.9458 \\
\hline $1.5 \times 10^{-3}$ & 15 & 0.3058 & 0.8485 & 44238 & 0.9694 \\
\hline $1.1 \times 10^{-3}$ & 11 & 0.2487 & 0.7511 & 20879 & 0.9434 \\
\hline $7.5 \times 10^{-4}$ & 7.5 & 0.2084 & 0.7606 & 13811 & 0.9370 \\
\hline $2.2 \times 10^{-4}$ & 2.2 & 0.0768 & 0.7367 & 1889.9 & 0.8159 \\
\hline $1.1 \times 10^{-4}$ & 1.1 & 0.0448 & 0.7067 & 885.19 & 0.7543 \\
\hline
\end{tabular}

order. The results illustrated that the color removal kinetics of RR 120 followed the second-order model very well. Fig.(3) shows that the RR 120 color removal kinetic rates at affixed $\mathrm{Fe}^{2+}$ concentration of $1.0 \times 10^{-4} \mathrm{M}$ increase with the $\mathrm{H}_{2} \mathrm{O}_{2}$ concentration in two different steps: (1) For the lowest amount of $\mathrm{H}_{2} \mathrm{O}_{2}$ ranged from $1.1 \times 10^{-4}$ to $1.1 \times 10^{-3} \mathrm{M}$, the RR 120 color removal kinetics increased slowly with a slope of $2.0 \times 10^{7}$; and higher regression coefficient value $\left(\mathrm{R}^{2}=0.9969\right)$. (2) while, increasing the $\mathrm{H}_{2} \mathrm{O}_{2}$ from $1.1 \times 10^{-3}$ to $5.0 \times 10^{-3} \mathrm{M}$, RR 120 color removal kinetics increases with a higher slope of $1.0 \times 10^{8}$ and lower correlation coefficient value $\left(R^{2}=0.9814\right)$ Fig.(3), the positive effect on the RR 120 color removal kinetics values at high $\mathrm{H}_{2} \mathrm{O}_{2}$ concentration is because of the higher production of hydroxyl free radical. When $\mathrm{H}_{2} \mathrm{O}_{2}$ concentration was greater than $1.1 \times 10^{-3} \mathrm{M}$ Fig.(3), the RR 120 color removal kinetics increased linearly with the $\mathrm{H}_{2} \mathrm{O}_{2}$ concentration with lower regression coefficient value. It suggests that the overdosed $\mathrm{H}_{2} \mathrm{O}_{2}$ was scavenging hydroxyl free radicals excessively (Eq. 9). Therefore, $1.1 \times 10^{-3} \mathrm{M} \mathrm{H}_{2} \mathrm{O}_{2}$ was chosen as the optimum concentration on $\mathrm{RR}$ 120 color removal kinetics.

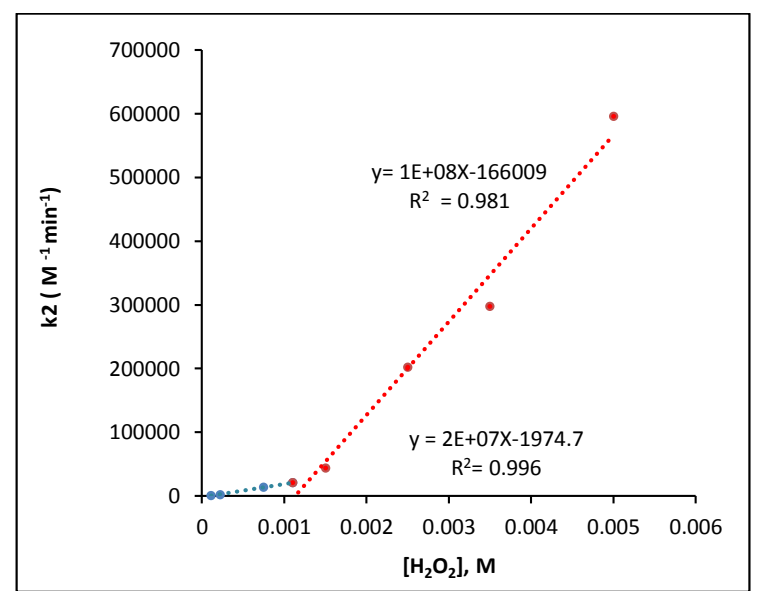

Fig.(3): Correlations between the secondorder kinetic constants versus $\mathrm{H}_{2} \mathrm{O}_{2}$ concentrations, during $R R 120$ color removal by Fenton oxidation. Experimental conditions: $[\mathrm{RR} 120]=7.5 \times 10^{-5} \mathrm{M} ;\left[\mathrm{Fe}^{2+}\right]=$ $1.0 \times 10^{-4} \mathrm{M}$ and $\mathrm{pH}=3.5$.

\section{Effect of $\mathrm{Fe}^{2+}$ doses on the removal of $\mathrm{RR}$ 120}

The influence of $\mathrm{Fe}^{2+}$ (catalyst) concentration on the removal of RR 120 was examined by using the different $\mathrm{Fe}^{2+}$ concentrations from $1.0 \times 10^{-5}$ to $1.0 \times 10^{-3} \mathrm{M}$ while $\mathrm{H}_{2} \mathrm{O}_{2}$ concentration was fixed at $1.1 \times 10^{-3}$ M. As can be observed in Fig.(4), the removal rate for $\mathrm{RR} 120$ was enhanced by increasing the $\mathrm{Fe}^{2+}$ concentration from $1.0 \times 10^{-5}$ to $1.0 \times 10^{-4} \mathrm{M}$ and the color removal from $43.9 \%$ and $94.0 \%$ respectively was a achieved at $10 \mathrm{~min}$ of the reaction. This is due the fact that $\mathrm{Fe}^{2+}$ plays very important role in initiating the decompositions of $\mathrm{H}_{2} \mathrm{O}_{2}$ to generate hydroxyl free radicals in the Fenton process, which reacted with RR 120 instantly; resulting in the increase of RR 120 degradation [9]. Contrariwise, further increasing the $\mathrm{Fe}^{2+}$ concentration higher than $1.0 \times 10^{-4} \mathrm{M}$, there is no significant enhancement in Fenton oxidation. The observed decrease in RR 120 decomposition rate upon increasing the $\mathrm{Fe}^{2+}$ concentration may be attributed to the role of $\mathrm{Fe}^{2+}$ as scavenger of hydroxyl radicals (Eq.(10)). Therefore, the optimal $\mathrm{Fe}^{2+}$ concentration for the removal of RR 120 was $1.0 \times 10^{-4} \mathrm{M}$.

$$
\begin{aligned}
& \mathrm{Fe}^{2+}+\mathrm{HO}^{\cdot} \longrightarrow \mathrm{Fe}^{3+}+\mathrm{OH}^{-} \\
& k_{2}=3 \times 10^{8} \quad \mathrm{M}^{-1} \cdot \mathrm{S}^{-1}
\end{aligned}
$$




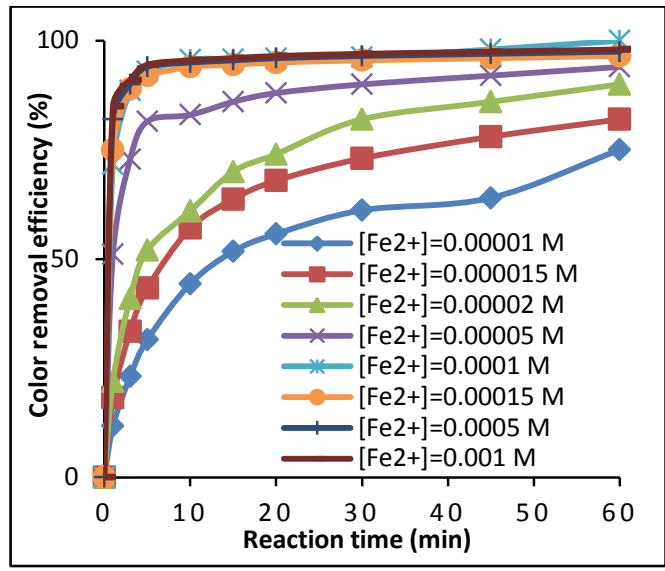

Fig.(4): RR 120 color removal by Fenton oxidation at various $\mathrm{Fe}^{+2}$ concentrations. Experimental conditions: $\left[R R\right.$ 120] $=7.5 \times 10^{-}$ $\mathrm{M} ;\left[\mathrm{H}_{2} \mathrm{O}_{2}\right]=1.1 \times 10^{-3} \mathrm{M}$ and $\mathrm{pH}=3.5$.

The kinetics of influence of $\mathrm{Fe}^{2+}$ concentration on RR120 color removal

To evaluate the effect of $\mathrm{Fe}^{2+}$ concentrations on decolorization kinetics of RR 120, two kinetic models were studied. Table(3) shows that the value of the regression coefficient $\left(\mathrm{R}^{2}\right)$ values of the second-order kinetic is the highest in the predominantly of the first order and this shows that the color removal kinetics of RR 120 follow the secondorder kinetics model. The correlation between second-order kinetics of the RR 120 color removal and different $\mathrm{Fe}^{2+}$ concentrations (from $1.0 \times 10^{-5}$ to $1.0 \times 10^{-3} \mathrm{M}$ ) are presented in Fig.(5). Fig.(5) elucidates that the RR 120 color removal kinetic rates increase with the $\mathrm{Fe}^{2+}$ concentration in two different steps as well: (1) For the lowest dose of $\mathrm{Fe}^{2+}$ ranged from $\left(1.0 \times 10^{-5}\right.$ to $\left.1.0 \times 10^{-4} \mathrm{M}\right)$, the $\mathrm{RR} 120$ color removal kinetics increased sharply with a slope of $\left(2.0 \times 10^{8}\right)$; (2) whilst increasing the concentration of $\mathrm{Fe}^{2+}$ (from $1.0 \times 10^{-4}$ to $\left.1.0 \times 10^{-3} \mathrm{M}\right)$, RR 120 color removal kinetics increased too with slower slope of $\left(1.0 \times 10^{7}\right)$. The slower color removal kinetics in the second step than the first step suggests that $\mathrm{Fe}^{2+}$ is overdosed by consumption considerable amount of hydroxyl free radicals (Eq.(10)). Thus, the amount of hydroxyl free radicals available to oxidize RR 120 dye will be very low. The positive effect of $\mathrm{Fe}^{2+}$ on the RR 120 color removal kinetics assured that $\mathrm{Fe}^{2+}$ acts as catalyst by rapid dissociation of $\mathrm{H}_{2} \mathrm{O}_{2}$ into $\mathrm{HO}^{\circ}$ radicals; due to $\mathrm{Fe}^{2+}$ not able to oxidize organic molecules. When $\mathrm{Fe}^{2+}$ dose is more than $1.0 \times 10^{-4} \mathrm{M}$ Fig.(5); the RR 120 color removal kinetics rate increased linearly with lower intensity by scavenging $\mathrm{HO}^{\circ}$ radicals. Thus, $1.0 \times 10^{-4} \mathrm{M} \mathrm{Fe}^{2+}$ was chosen as optimum concentration.

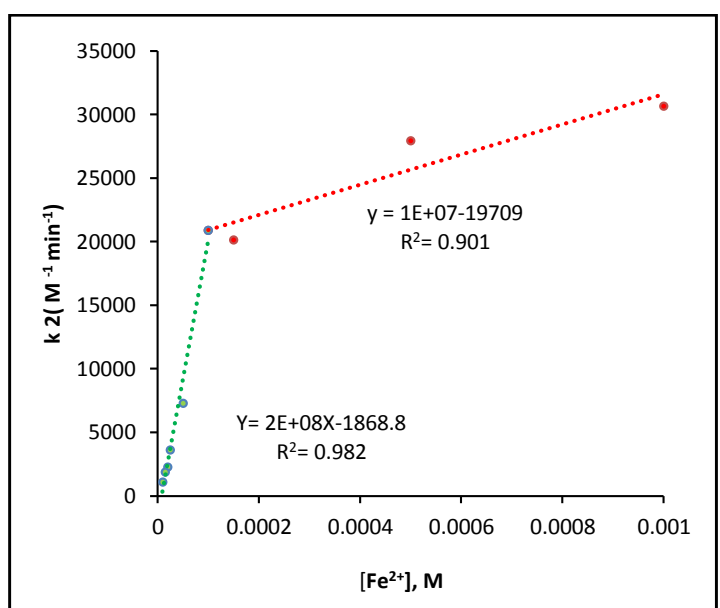

Fig.(5): Correlations between the secondorder kinetic constants versus $F^{2+}$ concentrations, during $R R 120$ color removal by Fenton oxidation. Experimental conditions: $[\mathrm{RR} 120]=7.5 \times 10^{-5} \mathrm{M} ;\left[\mathrm{H}_{2} \mathrm{O}_{2}\right]=$ $1.1 \times 10^{-3} \mathrm{M}$ and $\mathrm{pH}=3.5$.

Table (3)

First- and second- orders kinetic parameters and regression coefficients for each $\mathrm{Fe}^{2+}$ concentrations. Experimental conditions: $\left[R R\right.$ 120] $=7.5 \times 10^{-5} \mathrm{M} ;\left[\mathrm{H}_{2} \mathrm{O}_{2}\right]=1.1 \times 10^{-3} \mathrm{M}$ and $\mathrm{pH}=3.5$.

\begin{tabular}{|c|c|c|c|c|c|}
\hline \multirow{2}{*}{$\begin{array}{c}{\left[\mathrm{Fe}^{+2}\right]} \\
(\mathrm{M})\end{array}$} & \multirow[b]{2}{*}{$\begin{array}{l}\mathrm{H}_{2} \mathbf{O}_{2} \\
/ \mathrm{Fe}^{+2}\end{array}$} & \multicolumn{2}{|c|}{ First order } & \multicolumn{2}{|c|}{ Second order } \\
\hline & & $K 1\left(\min ^{-1}\right)$ & $R^{2}$ & $\begin{array}{c}K 2\left(M^{-1}\right. \\
\left.\min ^{-1}\right)\end{array}$ & $\mathbf{R}^{2}$ \\
\hline $1.0 \times 10^{-5}$ & 110 & 0.0563 & 0.968 & 1112.3 & 0.9906 \\
\hline $1.5 \times 10^{-5}$ & 73 & 0.0814 & 0.9533 & 1895.6 & 0.9906 \\
\hline $2.0 \times 10^{-5}$ & 55 & 0.0909 & 0.9002 & 2264.9 & 0.9588 \\
\hline $2.5 \times 10^{-5}$ & 44 & 0.1202 & 0.9197 & 3629.6 & 0.9876 \\
\hline $5.0 \times 10^{-5}$ & 22 & 0.7526 & 0.1629 & 7296.7 & 0.8574 \\
\hline $1.0 \times 10^{-4}$ & 11 & 0.2487 & 0.7511 & 20879 & 0.9434 \\
\hline $1.5 \times 10^{-4}$ & 7.3 & 0.2405 & 0.7156 & 20146 & 0.9306 \\
\hline $5.0 \times 10^{-4}$ & 2.2 & 0.2495 & 0.6783 & 27944 & 0.9025 \\
\hline $1.0 \times 10^{-3}$ & 1.1 & 0.2517 & 0.6546 & 30655 & 0.9056 \\
\hline
\end{tabular}

Influence of $\mathrm{H}_{2} \mathrm{O}_{2} / \mathrm{Fe}^{2+}$ molar ratio on $\mathrm{RR}$ 120 decolorization kinetics

Concentrations of $\mathrm{H}_{2} \mathrm{O}_{2}$ and $\mathrm{Fe}^{2+}$ are important parameters to optimize for the determination of the ratio $\mathrm{H}_{2} \mathrm{O}_{2} / \mathrm{Fe}^{2+}$ to accomplish maximum color removal efficiency of RR 120 from aqueous solutions and this ratio has been used in the following experiments. Several studies have been 
reported the optimum molar ratio of $\mathrm{H}_{2} \mathrm{O}_{2} / \mathrm{Fe}^{2+}$ was disparate for color removal of azo dyes. For example the molar ratio of $\mathrm{H}_{2} \mathrm{O}_{2} / \mathrm{Fe}^{2+}$ was 20:1 for C.I. Reactive Blue 4 and C.I. Reactive Red 2 [22], while the ratio was 40:1 for Reactive Black 5 [23]. These differences may be attributed to various oxidation mechanisms during the Fenton oxidation process of different azodyes. From the results which were listed in Table (2) and Table (3) the optimum concentrations for $\mathrm{H}_{2} \mathrm{O}_{2}$ and $\mathrm{Fe}^{2+}$ were $1.1 \times 10^{-3} \mathrm{M}$ and $1.0 \times 10^{-4} \mathrm{M}$, respectively. Therefore, the experimental optimal $\mathrm{H}_{2} \mathrm{O}_{2} / \mathrm{Fe}^{2+}$ molar ratio of 11 was chosen and was used in the next experiments.

\section{Effect of pH and $L_{\text {azo bond }}$ on RR 120 color removal kinetics}

To investigate the influence of $\mathrm{pH}$ on the color removal of RR 120 a series of experiments was conducted at three initial $\mathrm{pH}$ values (2.5, 3.5 and 5) as shown in Figure 6. The reaction was done for $60 \mathrm{~min}$ undercontrolled $\mathrm{pH}$ condition with constant concentration of $\mathrm{H}_{2} \mathrm{O}_{2}\left(1.1 \times 10^{-3} \mathrm{M}\right)$ and $\mathrm{Fe}^{2+}$ $\left(1.0 \times 10^{-4} \mathrm{M}\right)$. At $\mathrm{pH} 2.5$ the reaction of $\mathrm{H}_{2} \mathrm{O}_{2}$ with $\mathrm{Fe}^{2+}$ (Eq. (1)) is earnestly affected resulting the reduction in $\mathrm{HO}^{\circ}$ radical production. This may be attributed to $\mathrm{HO}^{\circ}$ scavenging by $\mathrm{H}^{+}$ions; which elucidate the decrease of the color removal efficiency at $\mathrm{pH} 2.5$ [24]. On the other hand, at $\mathrm{pH} 3.5$, the decolorization efficiency of RR 120 rapidly increased with the increase in $\mathrm{pH}$; at $\mathrm{pH} 3.5$ almost $100 \%$ of color removal efficiency was observed Fig.(6). The main reason is that more $\mathrm{Fe}(\mathrm{OH})^{+}$is formed; which has much higher activitycompared to $\mathrm{Fe}^{2+}$ in Fenton process [25]. In addition, at higher $\mathrm{pH}(\mathrm{pH} 5)$, the precipitation of ferric hydroxide happen, causing the reduction in the dissolving $\mathrm{Fe}^{3+}$ ions. Aside from, in such circumstances, $\mathrm{H}_{2} \mathrm{O}_{2}$ is less stable, resulting less $\mathrm{HO}^{\circ}$ radicals are formed, decreasing the removal efficiency of Fenton oxidation. [13]. Therefore, the $\mathrm{pH} 3.5$ is the optimum $\mathrm{pH}$ for Fenton oxidation process. The effect of four $L_{\mathrm{azo}}$ bond factor values $(0.25,0.5,0.75$, and 1.0$)$ at molar ratio $\mathrm{H}_{2} \mathrm{O}_{2} / \mathrm{Fe}^{2+}$ equal to 11 was evaluated. From the experimental data as shown in Table (4); the four levels of $L_{\text {azo bond }}$ are symbolized well by the second-order kinetic model. From Table(4) there is significant difference in RR 120 color removal rates at each $\mathrm{pH}$ and $L_{\mathrm{azo}}$ bond was observed.

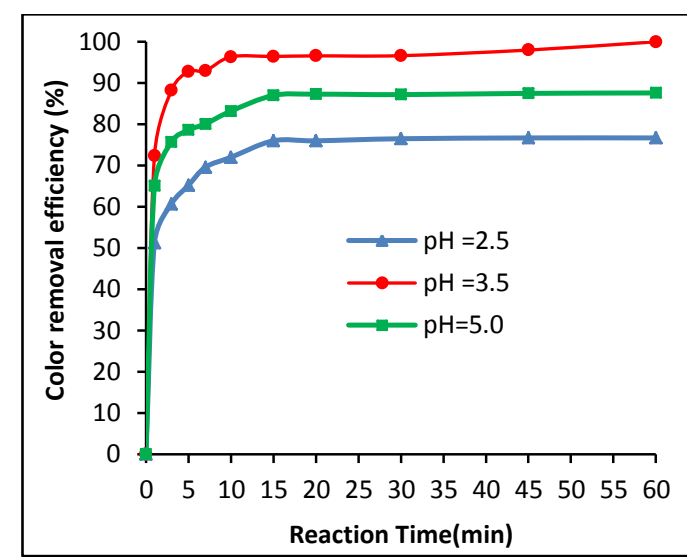

Fig.(6) Effect of $p H$ on the color removal efficiency of RR 120 by Fentonprocess. Experimental conditions:

$[R R 120]=7.5 \times 10^{-5} \mathrm{M} ;\left[\mathrm{Fe}^{2+}\right]=1.0 \times 10^{-4} \mathrm{M}$; $\left[\mathrm{H}_{2} \mathrm{O}_{2}\right]=1.1 \times 10^{-3} \mathrm{M}$.

Also, Table (4) shows that the best color removal rates of $\mathrm{RR} 120$ dye take place at $\mathrm{pH}$ 3.5. Our results are in harmony with previous work for assessment the color removal of Amido black 10B [26] and Terasil Red R [27]. The best RR 120 color removal rates were obtained at the lowest $L_{\text {azo bond }}$ factor 0.25 and higher $\mathrm{k}_{2}$ values; due to the lower $L_{\mathrm{azo}}$ bond factor represented a higher amount of $\mathrm{H}_{2} \mathrm{O}_{2}$ concentration per mole of RR 120 and coincides with the higher $\mathrm{O}_{2}$ concentration able to be used for oxidizing the RR 120 dye. Fig.(7) presents a linear correlation between the second-order kinetic model $\mathrm{k}_{2}$ value and the $L_{\text {azo bond }}$ at each $\mathrm{pH}$ value.

Table (4)

Second-order kinetic model and regression coefficients for each $\mathrm{pH}$ and $L_{\text {azo bond }}$ value during Fenton oxidation of $7.5 \times 10^{-5} M R R$ 120.

\begin{tabular}{|c||c||c||c||c||}
\hline $\mathbf{p H}$ & $\begin{array}{c}\boldsymbol{L}_{\text {azo bond }} \\
\mathbf{1 . 0}\end{array}$ & $\begin{array}{c}\boldsymbol{L}_{\text {azo bond }} \\
\mathbf{0 . 7 5}\end{array}$ & $\begin{array}{c}\boldsymbol{L}_{\text {azo bond }} \\
\mathbf{0 . 5}\end{array}$ & $\begin{array}{c}\boldsymbol{L}_{\text {azo bond }} \\
\mathbf{0 . 2 5}\end{array}$ \\
\hline \hline \multirow{2}{*}{$\mathbf{2 . 5}$} & $k 2=66.81$ & $k 2=82.6$ & $k 2=150$ & $k 2=465.3$ \\
& $R^{2}=0.641$ & $R^{2}=0.770$ & $R^{2}=0.654$ & $R^{2}=0.751$ \\
\hline \multirow{2}{*}{$\mathbf{3 . 5}$} & $k 2=651.5$ & $k 2=818.21$ & $k 2=1327.5$ & $k 2=4244.6$ \\
& $R^{2}=0.986$ & $R^{2}=0.981$ & $R^{2}=0.982$ & $R^{2}=0.986$ \\
\hline \hline \multirow{2}{*}{$\mathbf{5 . 0}$} & $k 2=284.2$ & $k 2=329.6$ & $k 2=353.4$ & $k 2=1787.5$ \\
& $R^{2}=0.771$ & $R^{2}=0.726$ & $R^{2}=0.627$ & $R^{2}=0.888$ \\
\hline \hline
\end{tabular}




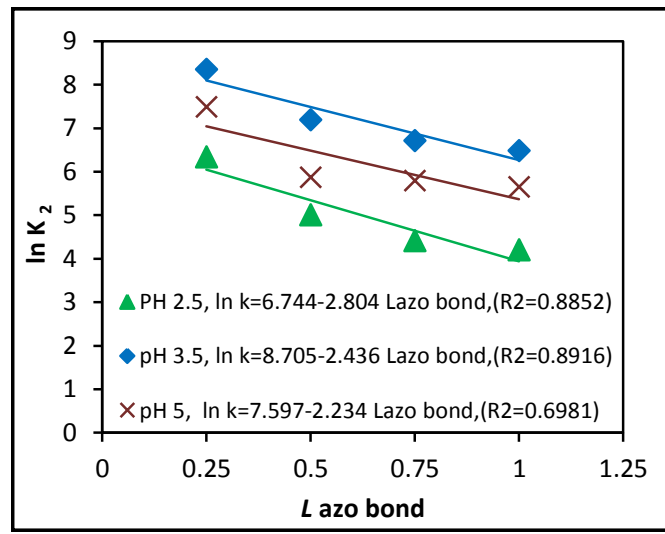

Fig.(7): Correlations between $\ln k_{2}$ of the color removal rates versus $L_{a z o}$ bond $a t$ different $\mathrm{pH}$ values obtained during Fenton oxidation of $7.5 \times 10^{-5} \mathrm{M} R R 120$.

\section{COD removal of $R R 120$ at different $L_{C O D}$ factors}

Although homogeneous catalytic process removed the color of azo-dye solution, the RR120 azo dye has not been mineralized, completely. For this reason it is necessary consider complementary information about the degradation of the organic pollutants [28]. Chemical oxygen demand (COD) gives an average measure of the oxidation state of the organic byproducts generated during the degradation of dye RR 120 [29]. Under the best $\mathrm{pH}$ of 3.5 and mole ratio of $\mathrm{H}_{2} \mathrm{O}_{2} / \mathrm{Fe}^{2+}$ equal to 11 which were determined formerly, experiments using four different $L_{\text {COD }}$ values $(0.25,0.5,0.75,1.0)$ were performed to investigate the efficiency of Fenton process on COD removal kinetics of RR120 is shown in Fig.(8). The COD removal increases with decreasing $L_{\mathrm{COD}}$ because the theoretical amount of the concentration of $\mathrm{H}_{2} \mathrm{O}_{2}$ and $\mathrm{Fe}^{2+}$ it has increase. At the maximum $\left(L_{\mathrm{COD}}=1.0\right)$ was observed $55.7 \%$ of COD removal were accomplished after 15 min while at the minimum $\left(L_{\mathrm{COD}}=0.25\right)$ was observed $67 \%$ of COD removal were achieved after the same time. These results show there was residual $\mathrm{H}_{2} \mathrm{O}_{2}$ in solution after $15 \mathrm{~min}$ of Fenton's oxidation reaction Fig.(9), perhaps all the $\mathrm{Fe}^{2+}$ was converted to $\mathrm{Fe}^{3+}$, decreasing the reaction rate with $\mathrm{H}_{2} \mathrm{O}_{2}$, since a slower consumption of $\mathrm{H}_{2} \mathrm{O}_{2}$ was observed Fig.(9). The results of consumption of $\mathrm{H}_{2} \mathrm{O}_{2}$ showed that for Fenton oxidation, the $81.6 \% \mathrm{H}_{2} \mathrm{O}_{2}$ was consumed after $15 \mathrm{~min}$ at $L_{\mathrm{COD}}=1.0$ while only about $43 \% \quad \mathrm{H}_{2} \mathrm{O}_{2}$ was consumed at $L_{\mathrm{COD}}=0.25$.

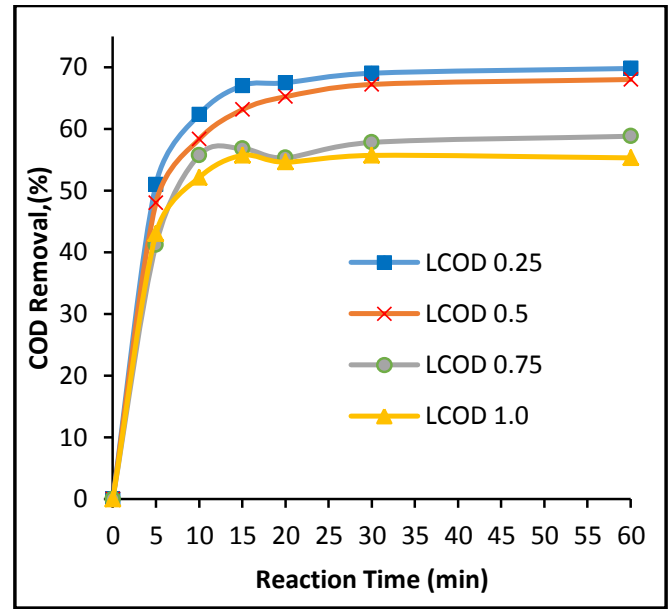

Fig.(8): Correlation between the COD removal of $7.5 \times 10^{-5} M R R 120(C O D=124$ $\left.m g \mathrm{O}_{2} L^{-1}\right)$ versus reaction time. Experimental conditions: $\mathrm{pH}=3.5$ and molar ratio $\mathrm{H}_{2} \mathrm{O}_{2} / \mathrm{Fe}^{2+}=11$.

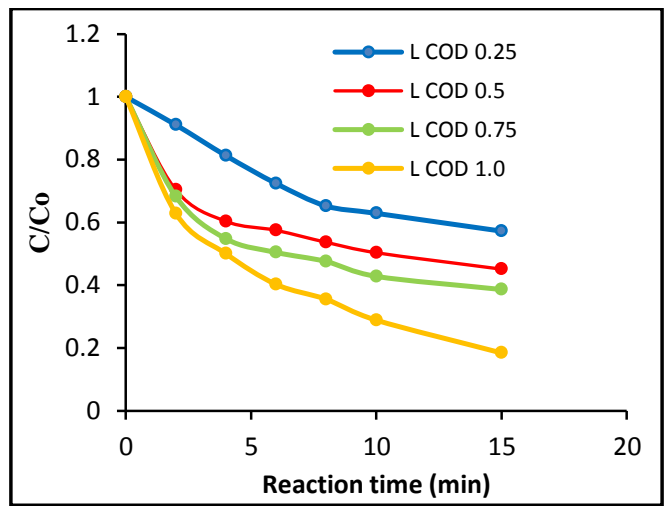

Fig.(9): The consumption of $\mathrm{H}_{2} \mathrm{O}_{2}$ using different $L_{C O D}$ factor. Experimental conditions: [RR 120] $=7.5 \times 10^{-5} \mathrm{M} \mathrm{pH=3.5}$ and molar ratio $\mathrm{H}_{2} \mathrm{O}_{2} / \mathrm{Fe}^{2+}=11$.

Effect of RR 120 concentration on color removal kinetics

The color removal efficiency of different concentrations of RR 120 was studied. It was observed from Fig.(10) that the color removal of dye increases with the decrease in initial RR 120 concentration. As the concentration of dye decrease from $1.5 \times 10^{-4} \mathrm{M}$ to $5.0 \times 10^{-5} \mathrm{M}$, the decolorization efficiency of dye increase from $45 \%$ to $96 \%$ within the first $10 \mathrm{~min}$ of reaction. A decrease in the concentration of RR 120 dye reveals that little dye molecules will be available to scavenging by $\mathrm{HO}^{\circ}$ radicals which lead to increase in the color removal efficiency of RR 120 [30]. 


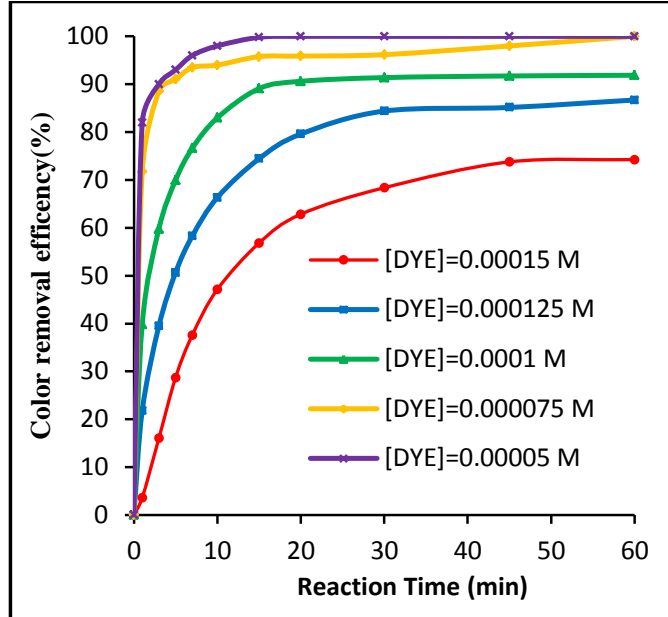

Fig.(10): Effect of initial RR120 concentration on its color removal efficiency during Fenton oxidation. Experimental conditions: $\left[\mathrm{H}_{2} \mathrm{O}_{2}\right]=1.1 \times 10^{-3} \mathrm{M} ;\left[\mathrm{Fe}^{2+}\right]$

$$
=1.0 \times 10^{-4} \mathrm{M} \text { and } \mathrm{pH}=3.5 \text {. }
$$

Table (5) presents the second-order kinetic rates of color removal of RR 120 at various RR 120 concentrations. Also, Table (5) shows the effect of different $\left[\mathrm{H}_{2} \mathrm{O}_{2}\right] /[$ dye] ratios as a function of color removal kinetics of RR 120 . It is obvious that the color removal kinetics increase with the decrease in RR 120 concentration in two different steps. A tenuous increase in color removal kinetic rate (from 611.8 to $4728.5 \mathrm{M}^{-1} \mathrm{~min}^{-1}$ ) occurred when the ratio $\left[\mathrm{H}_{2} \mathrm{O}_{2}\right] /[$ dye] increases from 7.3 to 11 . However, increasing the $\mathrm{H}_{2} \mathrm{O}_{2}$ /dye ratio from 11 to 22 , there was a acute increase in color removal kinetic rate (from 4728.5 to 50971 $\mathrm{M}^{-1} \mathrm{~min}^{-1}$ ). Furthermore, the efficiency of RR 120 color removal, increases with decreasing $\left[\mathrm{H}_{2} \mathrm{O}_{2}\right] /[\mathrm{RR}$ 120] molar ratio, which points out that a higher concentration of RR 120 was removed by using smaller dose of $\mathrm{H}_{2} \mathrm{O}_{2}$ Fig.(10).

Table (5)

Second-order kinetic constants and regression coefficients for each RR120 concentration during Fenton oxidation Experimental conditions: $\left[\mathrm{Fe}^{2+}\right]=1.0 \times 10^{-4}$ $\mathrm{M} ;\left[\mathrm{H}_{2} \mathrm{O}_{2}\right]=1.1 \times 10^{-3} \mathrm{M}$ and $\mathrm{pH}=3.5$.

\begin{tabular}{|c||c|c||c||}
\hline $\begin{array}{c}{[\mathbf{R R 1 2 0}]} \\
(\mathbf{M})\end{array}$ & $\begin{array}{c}{\left[\mathbf{H}_{2} \mathbf{O}_{2}\right] /} \\
{[\mathbf{R R ~ 1 2 0}]}\end{array}$ & $\boldsymbol{K} 2\left(\mathbf{M}^{-1} \mathbf{m i n}^{-1}\right)$ & $\boldsymbol{R}^{2}$ \\
\hline \hline $1.5 \times 10^{-4}$ & 7.3 & 611.89 & 0.9932 \\
\hline \hline $1.25 \times 10^{-4}$ & 8.8 & 1544.6 & 0.9983 \\
\hline $1.0 \times 10^{-4}$ & 11 & 4728.5 & 0.9977 \\
\hline \hline $7.5 \times 10^{-5}$ & 14.6 & 20879 & 0.9434 \\
\hline \hline $5 \times 10^{-5}$ & 22 & 50971 & 0.9671 \\
\hline
\end{tabular}

The influence of inorganic ions on RR 120 color removal by Fenton oxidation

The influence of some inorganic anions on the color removal of RR 120 was tested in the optimum conditions. To simulate an aqueous solution containing RR 120 at concentration of $\left(110.3 \mathrm{mg} \mathrm{L}^{-1} ; 7.5 \times 10^{-5} \mathrm{M}\right)$ in the presence of $1.0 \%$ of inorganic salt used in this study. Consequently, we intend to assess the color removal of RR 120 by the Fenton oxidation process containing high doses of selected inorganic salts; due to a large quantity of anions are predominantly present in industrial textile wastewater. Fenton oxidation is highly sensitive to inorganic anions which remain in the aqueous solution [31]. In this research, the influences of chloride, sulfate, carbonate and bicarbonate on the Fenton process were evaluated. Fig.(11) show the effect of the studied anions on the RR120 degradation by Fenton oxidation process. Anions suppress the degradation of RR 120 in the following sequence:

$\mathrm{HCO}_{3}{ }^{-}>\mathrm{CO}_{3}^{-2}>\mathrm{Cl}^{-}>\mathrm{SO}_{4}{ }^{-2}$

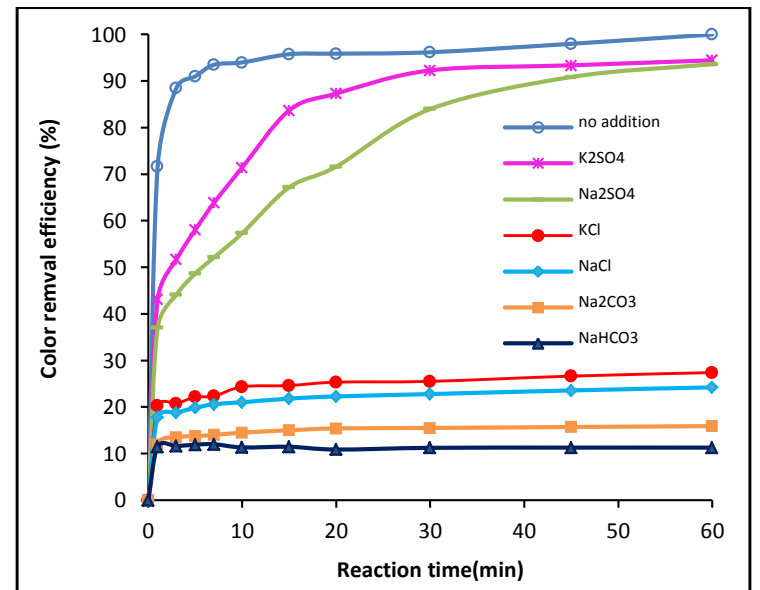

Fig.(11): Effect of addition of 1.0\% inorganic anionic on $R R 120$ color removal efficiency. Experimental conditions: $\left[R R\right.$ 120] $=7.5 \times 10^{-}$ ${ }^{5} \mathrm{M} ;\left[\mathrm{Fe}^{2+}\right]=1.0 \times 10^{-4} \mathrm{M} ;\left[\mathrm{H}_{2} \mathrm{O}_{2}\right]=1.1 \times 10^{-3} \mathrm{M}$ and $\mathrm{pH}=3.5$.

The addition of inorganic anions displayed various inhibiting behaviors in Fenton process treatment. The influence of the addition of $\mathrm{HCO}_{3}{ }^{-}$and $\mathrm{CO}_{3}^{-2}$ may be attributed to a decrease of the rate of generation of hydroxyl radicals because the formation of $\mathrm{CO}_{3}{ }^{\circ-}$ (Eqs. (11) and (12)).

$\mathrm{HO}^{\circ}+\mathrm{HCO}_{3}^{-} \longrightarrow \mathrm{H}_{2} \mathrm{O}+\mathrm{CO}_{3}{ }^{-}$

$\mathrm{HO}^{\circ}+\mathrm{CO}_{3}^{2-} \longrightarrow \mathrm{OH}^{-}+\mathrm{CO}_{3}{ }^{\circ-}$ 
The radical $\mathrm{CO}_{3}{ }^{\circ-}$ is less reactive than $\mathrm{HO}^{\circ}$ radicals. In the case of $\mathrm{Cl}^{-}$it also has a great effect on the decomposition of RR120 because it reacts with $\mathrm{Fe}^{2+}$ forming complex and free radical less effective than the radical of hydroxyl (Eqs. (13) and (14)) [32].

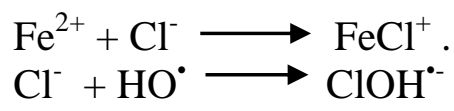

The salts of the sulfate ion appear to have less effect on the Fenton process, where sulfate ion react with $\mathrm{Fe}^{2+}$ and $\mathrm{HO}^{\circ}$, a component $\mathrm{HO}^{\circ}$ (Eqs. (15) and (16)) [33].

$$
\begin{aligned}
& \mathrm{Fe}^{2+}+\mathrm{SO}_{4}{ }^{2-} \longrightarrow \mathrm{FeSO}_{4} \ldots \ldots \ldots \\
& \mathrm{HSO}_{4}^{-}+\mathrm{HO}^{-} \longrightarrow \mathrm{SO}_{4}{ }^{--}+\mathrm{H}_{2} \mathrm{O}
\end{aligned}
$$

\section{Conclusions}

In this study, the characteristic of COD and color removal of azo dye by Fenton process treatment was evaluated for Reactive Red 120 in aqueous solution. It has been selected amongst azo dyes due to its high solubility in aquatic environment and it is widely used from Al-Kut textile factory. The degradation of RR 120 aqueous solution strongly depends on the system parameters such as $\mathrm{pH}$, hydrogen peroxide and ferrous catalyst concentration, $\mathrm{H}_{2} \mathrm{O}_{2} / \mathrm{Fe}^{2+}$ mole ratio, and dye concentration. Based on the result, the following conclusions were derived:

1.The experiments showed that RR 120 at a concentration of $7.5 \times 10^{-5} \mathrm{M}$ can be degraded using the optimum $\mathrm{H}_{2} \mathrm{O}_{2} / \mathrm{Fe}^{2+}$ molar ratio was determined to be 11 .

2.The COD removal increases with decreasing $L_{\mathrm{COD}}$. The maximum $\left(L_{\mathrm{COD}} 1.0\right)$ was observed $55.7 \%$ of COD removal were achieved after $15 \mathrm{~min}$ while at the minimum $\left(L_{\mathrm{COD}} 0.25\right)$ was observed $67 \%$

3.of COD removal were achieved after the same time.

4.The optimum conditions were obtained at $\mathrm{pH}$ of 3.5 and the $\mathrm{H}_{2} \mathrm{O}_{2} / \mathrm{Fe}^{2+}$ molar ratio of 11. Under the optimum condition, almost complete color degradation resulted for RR 120.

5.This research has shown that removal efficiency of the Fenton oxidation process can be decreased in the presence of $1.0 \%$ of inorganic salt according to the following sequence: $\mathrm{HCO}_{3}^{-}>\mathrm{CO}_{3}^{-2}>\mathrm{Cl}^{-}>\mathrm{SO}_{4}{ }^{-2}$.

\section{References}

[1] Paul S., Chavan S., and Khambe S., "Studies on characterization of textile industrial waste water in Solapur city". International Journal of Chemical Sciences, 10, 635-642, 2012.

[2] Wang Z., Xue M., Huang K.,and Liu Z., "Textile dyeing wastewater treatment", in: Advances in treating textile effluent, InTech, 2011.

[3] Garcia-Segura S., and Brillas E., "Combustion of textile monoazo, diazo and triazo dyes by solar photoelectro-Fenton: decolorization, kinetics and degradation routes". Applied Catalysis B: Environmental, 181 ,681-691, 2016.

[4] Holkar C.R., Jadhav A.J., Pinjari D.V., Mahamuni N.M., and Pandit A.B., "A critical review on textile wastewater treatments: possible approaches.," Journal of environmental management, 182,351366, 2016.

[5] Nidheesh P.V., Gandhimathi R.,and Ramesh S.T., "Degradation of dyes from aqueous solution by Fenton processes": a review, Environmental Science and Pollution Research, 20,2099-2132, 2013.

[6] Galán J., Rodríguez A., Gómez J., Allen S., and Walker G., "Reactive dye adsorption onto a novel mesoporous carbon". Chemical engineering journal,219,62-68, 2013.

[7] Dewil R., Mantzavinos D., Poulios I.,and Rodrigo M.A. "New perspectives for Advanced Oxidation Processes". Journal of environmental management, 195,93-99, 2017.

[8] Faouzi M., Canizares P., Gadri A., Lobato J., Nasr B., Paz R., Rodrigo M., and Saez C. "Advanced oxidation processes for the treatment of wastes polluted with azoic dyes". Electrochimica Acta, 52,325-331, 2006.

[9] Ertugay N., and Acar F.N., "Removal of COD and color from Direct Blue 71 azo dye wastewater by Fenton's oxidation". Kinetic study, Arabian Journal of Chemistry, 10, 1158-1163, 2017.

[10] Trovó A., Hassan A., Sillanpää M., and Tang W., "Degradation of Acid Blue 161 by Fenton and photo-Fenton processes". International Journal of Environmental 
Science and Technology, 13, 147-158, 2016.

[11] Lachheb H., Puzenat E., Houas A., Ksibi M., Elaloui E., Guillard C., and Herrmann J-M., "Photocatalytic degradation of various types of dyes (Alizarin S, Crocein Orange G, Methyl Red, Congo Red, Methylene Blue) in water by UV-irradiated titania". Applied Catalysis B: Environmental, 39, 75-90, 2002.

[12] Mousset E., Oturan N., Van Hullebusch E.D., Guibaud G., Esposito G., and Outran M.A., "Treatment of synthetic soil washing solutions containing phenanthrene and cyclodextrin by electro-oxidation. Influence of anode materials on toxicity removal and biodegradability enhancement". Applied Catalysis B: Environmental, 160,666-675, 2014.

[13] Brillas E., Sirés I., and Oturan M.A., "Electro-Fenton process and related electrochemical technologies based on Fenton's reaction chemistry" Chemical reviews. 109, 6570-6631, 2009

[14] Karkmaz M., Puzenat E., Guillard C., and Herrmann J., "Photocatalytic degradation of the alimentary azo dye amaranth: Mineralization of the azo group to nitrogen". Applied Catalysis B: Environmental, 51,183-194, 2004.

[15] EPA, Method 410.4(1993). "The determination of chemical oxygen demand by semi-automated colorimetric". Accessed. Jun, 18, 2011.

[16] Nogueira R.F.P., Oliveira M.C., and Paterlin W.C., "Simple and fast spectrophotometric determination of $\mathrm{H}_{2} \mathrm{O}_{2}$ in photo-Fenton reactions using metavanadate". Talanta, 66, 86-91, 2005.

[17] Sun J.-H., Shi S.-H., Lee Y.-F., and Sun S.-P., "Fenton oxidative decolorization of the azo dye Direct Blue 15 in aqueous solution". Chemical Engineering Journal, 155, 680-683, 2009.

[18] Goi A., Veressinina Y., and Trapido M., "Fenton process for landfill leachate treatment: evaluation of biodegradability and toxicity". Journal of Environmental Engineering, 136, 46-53, 2009.

[19] Lopez-Alvarez B., Torres-Palma R.A., Ferraro F., and Peñuela G., "Solar photoFenton treatment of carbofuran: analysis of mineralization, toxicity, and organic byproducts". Journal of Environmental Science and Health, Part A, 47, 2141-2150, 2012.

[20] Wu T., and Englehardt J.D., "A new method for removal of hydrogen peroxide interference in the analysis of chemical oxygen demand". Environmental science \& technology, 46, 2291-2298, 2012.

[21] Tang WZ, (2004) physicochemical treatment of hazardous wastes. Lewis Publishers, Boca Raton.

[22] Agustina T.E., and Ang H., "Decolorization and mineralization of $\mathrm{CI}$ reactive blue 4 and $\mathrm{CI}$ reactive red 2 by fenton oxidation process". International Journal, 3, 3, 2012.

[23] Lucas M.S., and Peres J.A., "Decolorization of the azo dye Reactive Black 5 by Fenton and photo-Fenton oxidation". Dyes and Pigments, 71,236-244, 2006.

[24] Neamtu M.,Yediler A., Siminiceanu I., and Kettrup A., "Oxidation of commercial reactive azo dye aqueous solutions by the photo-Fenton and Fenton-like processes". Journal of Photochemistry and Photobiology A: Chemistry, 161, 87-93, 2003.

[25] Azbar N., Yonar T., and Kestioglu K., "Comparison of various advanced oxidation processes and chemical treatment methods for COD and color removal from a polyester and acetate fiber dyeing effluent, Chemosphere, 55, 35-43, 2004.

[26] Sun J.-H., Sun S.-P., Wang G.-L., and Qiao L.-P., "Degradation of azo dye Amido black $10 \mathrm{~B}$ in aqueous solution by Fenton oxidation process". Dyes and Pigments, 74,647-652, 2007.

[27] Woo Y.S., Rafatullah M., Al-Karkhi A.F.M., and Tow T.T., "Removal of Terasil Red R dye by using Fenton oxidation: a statistical analysis". Desalination and Water Treatment, 52, 4583-4591, 2014.

[28] Yu F., Li C., and Kang S., "Color, dye and DOC removal, and acid generation during Fenton oxidation of dyes". Environmental technology, 26, 537-544, 2005.

[29] Zhang F., Yediler A., and Liang X., "Decomposition pathways and reaction 
intermediate formation of the purified, hydrolyzed azo reactive dye CI Reactive Red 120 during ozonation". Chemosphere, 67, 712-717, 2007

[30] Liu X., Qiu M., and Huang C., "Degradation of the Reactive Black 5 by Fenton and Fenton-like system". Procedia Engineering, 15, 4835-4840, 2011.

[31] Oliveira T.D.d., Martini W.S., Santos M.D., Matos M.A.C., and Rocha L.L.d., "Caffeine oxidation in water by Fenton and Fenton-like processes: effects of inorganic anions and ecotoxicological evaluation on aquatic organisms". Journal of the Brazilian Chemical Society, 26,178-184, 2015.

[32] Sun J-H., Sun S-P., Sun J-Y., Sun R.-X., Qiao L.-P., Guo H-Q., and Fan M.-H., "Degradation of azo dye Acid black 1 using low concentration iron of Fenton process facilitated by ultrasonic irradiation". Ultrasonics sonochemistry, 14,761-766, 2007.

[33] Guinea E., Brillas E., Centellas F., Cañizares P., Rodrigo M.A., and Sáez C., "xidation of enrofloxacin with conductivediamond electrochemical oxidation, ozonation and Fenton oxidation". A comparison, Water research, 43, 21312138, 2009. 